\title{
Pengaruh Indikator Keuangan Perusahaan terhadap Harga Saham dalam Kelompok Jakarta Islamic Indeks
}

\author{
Irawati Junaeni \\ Perbanas Institute,Jakarta \\ ira.bwahyudi@gmail.com
}

\begin{abstract}
ABSTRAK
Penelitian ini bertujuan untuk menganalisis pengaruh indikator keuangan : Earming Per Share (EPS), Net Profit Margin (NPM), dan Suku Bunga Bank terhadap harga saham pada perusahaan dalam kelompok Jakarta Islamic Indeks. Sampel dari penelitian ini terdiri dari perusahaan dalam kelompok tersebut dan terdaftar di Bursa Efek Indonesia selama periode 20122017. Sesuai kriteria yang ditetapkan dalam penelitan ini diperoleh sebanyak 10 perusahaan. Penelitian ini menggunakan metode purposive sampling. Analisis data yang digunakan dalam penelitian ini adalah Analisis regresi data panel yang menggunakan tingkat signifikansi sebesar 0,05 atau 5\%. Hasil penelitian ini secara partial menunjukan bahwa: EPS dan NPM berpengaruh secara positif dan signifikan terhadap harga saham, namun suku bunga Bank Indonesia tidak berpengaruh terhadap harga saham. Secara simultan EPS, NPM, dan suku bunga Bank Indoenesia berpengaruh positif terhadap harga saham, dimana besarnya adjusted R squared 46,25 \%.
\end{abstract}

Kata Kunci: Earning Per Share, Net Profit Margin, Suku Bunga Bank Indonesia

\section{Pendahuluan}

Dalam menghadapi persaingan, perusahaan harus berupaya mempertahankan dan meningkatkan kinerja perusahaan sebagai upaya menjaga kelangsungan usahanya. Upaya yang dapat dilakukan antara lain menerapkan kebijakan strategis yang menghasilkan efisiensi dan efektivitas bagi perusahaan. Dalam menjalankan usaha tersebut memerlukan dana yang cukup banyak, yang meliputi usaha memperoleh dan mengalokasikan modal tersebut secara optimal. Salah satu tempat untuk memperoleh dana perusahaan adalah melalui pasar modal. Dalam berinvestasi di pasar modal, investor perlu memiliki sejumlah informasi yang berkaitan dengan harga saham untuk dapat mengambil keputusan tentang saham perusahaan yang layak untuk dipilih. Menurut Yulsiati (2016) Harga saham adalah nilai suatu saham yang mencerminkan kekayaan perusahaan yang mengeluarkan saham tersebut, dimana perubahan atau fluktuasinya sangat ditentukan oleh kekuatan penawaran dan permintaan yang terjadi di bursa (pasar sekunder)
Harga saham di pasar sekunder ditentukan oleh demand dan supply antara penjual dan pembeli. Harga saham sangat cepat untuk berubah ubah, untuk terhindar dari kerugian investor harus pandai dalam menganalisis harga saham. Dari sudut pandang pemegang saham,Menurut Husnan, S., \& Pudjiastuti (2015: 73) faktor-faktor yang berpengaruh terhadap harga pasar saham dapat dibagi menjadi 3 (tiga) kategori, yaitu faktor fundamental, faktor teknis, dan faktor sosial, ekonomi dan politik.

Penelitian ini menggunakan faktor fundamental dan faktor ekonomi yang merupakan faktor penting dan berpengaruh terhadap harga pasar saham yang berfluktuasi. Analisis faktor fundamental didasarkan pada laporan keuangan perusahaan yang dapat dianalisis melalui analisa rasio-rasio keuangan. Beberapa variabel rasio keuangan yang dijadikan sebagai alat ukur oleh investor dimana variabel tersebut mempengaruhi harga saham yang terdaftar pada Jakarta Islamic Index ( JII), antara lain Net Profit Margin (NPM) dan Earning Per Share (EPS). Selain faktor fundamental, terdapat faktor ekonomi melalui kebijakan moneter, yaitu variabel tingkat suku bunga. Perubahan BI 7 
Days Reverse Repo Rate akan mempengaruhi suku bunga SBI sebagai perantara awal yang dapat mempengaruhi fluktuasi harga saham.

Earning Per Share (EPS) merupakan perbandingan antara laba bersih setelah pajak pada satu tahun buku dengan jumlah saham yang diterbitkan. EPS yang tinggi menandakan bahwa perusahaan tersebut kondisi dan kinerjanya dalam keadaan baik. Penelitian Agustina, L., \& Noviri (2013) ketika EPS naik, biasanya permintaan terhadap saham tersebut akan naik sehingga harga saham perusahaan tersebut ikut meningkat . Sedangkan penelitian yang dilakukan oleh Pande Widya Rahmadewi (2018) menyatakan bahwa EPS tidak berpengaruh terhadap harga saham.

Net Profit Margin (NPM) merupakan perbandingan antara laba bersih dengan penjualan. Semakin besar rasio ini semakin baik karena kemampuan perusahaan dalam mendapatkan laba melalui penjualan cukup tinggi serta kemampuan perusahaan dalam menekan biaya-biayanya cukup baik, sehingga permintaan akan saham meningkat dan akan menaikkan harga saham perusahaan tersebut. Hal tersebut sejalan dengan penelitian yang dilakukan oleh Hutami (2012) yang menyatakan bahwa NPM berpengaruh positif dan signifikan terhadap harga saham. Namun penelitian yang dilakukan ole (Achmad Husaini (2012) menyatakan bahwa NPM tidak memiliki pengaruh terhadap harga saham.

Suku bunga Bank Indonesia adalah instrumen kebijakan yang digunakan untuk operasi pasar terbuka di bank sentral. Bank Indonesia melakukan penguatan kerangka operasi moneter dengan mengeluarkan suku bunga kebijakan baru yaitu BI 7-Days Reverse Repo Rate. Suku bunga kebijakan yang baru ini tidak mengubah pendirian kebijakan moneter yang sedang diterapkan (www.bi.go.id)

Jakarta Islamic Index (JII) adalah sebagai tolok ukur standar dan kinerja bagi investasi saham secara syariah di pasar modal dan sebagai sarana untuk meningkatkan investasi. Saham yang dipilih JII adalah saham-saham syariah yang termasuk ke dalam Daftar Efek Syariah (DES), dimana saham yang termasuk ke dalam DES mempunyai batasan total hutang yang berbasis bunga dibanding dengan total aset tidak lebih dari $45 \%$ atau total pendapatan bunga dan pendapatan tidak halal lainnya dibandingkan dengan total pendapatan usaha dan pendapatan lain tidak lebih dari 10\%, sehingga hutang perusahaan dalam kelompok JII terkendali dan pendapatanya stabil (www.idx.co.id)

Berdasarkan hasil-hasil penelitian tersebut, peneliti tertarik untuk menguji variabelvariabel bebas yang diduga mempengaruhi perubahan harga saham antara lain Earning Per Share, Net profit Margin dan tingkat suku bunga Bank Indonesia. Variabel-variabel ini pada umumnya pernah diteliti oleh peneliti-peneliti sebelumnya.

Pada penelitian ini, variabel-variabel dalam penelitian yang dibahas yaitu variabel bebas (independen) yang terdiri dari earning per share, net profit margin dan suku bunga BI, serta variabel terikat (dependen) yaitu harga saham.

\section{Landasan Teori}

\subsection{Harga Saham}

Saham merupakan tanda penyertaan atau kepemilikan seseorang/badan dalam suatu perusahaan. Selembar saham adalah selembar kertas yang menerangkan bahwa pemilik kertas tersebut adalah pemiliknya (berapapun porsinya / jumlahnya) dari suatu perusahaan yang menerbitkan kertas (saham) tersebut . hal tersebut disampaikan Elma Muncar Aditya dan Christian Budi Santoso (2012). Saham diterbitkan oleh perusahaan yang membutuhkan dana dalam bentuk modal sendiri atau ekuitas untuk dijual secara langsung kepada pemilik dana melalui pasar saham. Menurut Fahmi (2014 : 78) investasi pada pasar modal adalah invetasi yang bersifat jangka pendek karena keuntungan yang diterima berupa capital gain. Bagi para investor yang menyukai capital gain, di pasar modal ini merupakan tempat yang menarik dimana investor akan membeli saat harga turun dan menjual saat harga sedang naik.

Investor akan menilai perusahaan penerbit sebelum membeli di pasar modal. Jika perusahaan di nilai dalam kondisi baik maka biasanya harga saham akan mengalami kenaikan dan sebaliknya jika investor menilai perusahaan penerbit dalam kondisi buruk maka harga saham akan mengalami penurunan karena nilai atau harga saham ditentukan oleh kekuatan pasar di bursa. 
Dalam memilih saham investor memerlukan analisis agar menghindari resiko kerugian akibat salah memilih saham untuk berinvestasi. Disampaikan oleh Takarini, N. and Hendrarini H. (2011) Dari sudut pandang pemegang saham, faktor-faktor yang berpengaruh terhadap harga pasar saham akan membentuk kekuatan pasar yang berpengaruh terhadap transaksi dalam perusahaan sehingga harga pasar saham perusahaan akan mengalami berbagai kemungkinan kenaikan maupun penurunan harga, faktor-faktor tersebut antara lain:

1. Faktor fundamental, meliputi kemampuan manajemen perusahaan, prospek perusahaan, prospek pemasaran, perkembangan teknologi, profitabilitas, manfaat terhadap perekonomian nasional, kebijakan pemerintah, dan hak-hak investor atas dana yang diinvestasikan dalam perusahaan.

2. Faktor teknis, meliputi tentang perkembangan kurs, keadaan pasar modal, volume dan frekuensi perdagangan, dan kekuatan pasar modal.

3. Faktor sosial, ekonomi, dan politik meliputi tingkat inflasi, kebijakan moneter, neraca pembayaran luar negeri dan Anggaran Pendapatan dan Belanja Negara (APBN), kondisi perekonomian nasional, dan keadaan politik suatu negara.

\subsection{Earning Per Share}

Menurut Gitman, L. J., \& Zutter (2015:130) Earning Per Share (EPS) mewakili angka dolar yang diperoleh selama periode berjalan atas nama dari setiap bagian saham biasa yang beredar yang beredar. Artinya, EPS mampu menggambarkan kemampuan perusahaan dalam menghasilkan keuntungan bersih atas setiap lembar saham. EPS meningkat menandakan bahwa perusahaan berhasil meningkatkan taraf kemakmuran investor dan mendorongnya untuk menambah jumlah modal yang ditanamkan.

Teori yang disampaikan Gitman, L. J., \& Zutter (2015:130) besarnya EPS dapat dihitung

$$
\begin{aligned}
& \text { EPS } \\
& =\frac{\text { Penghasilan untuk pemegang saham }}{\text { Jumlah saham biasa yang beredar }}
\end{aligned}
$$

Hasil penelitian Safitri (2013) , Agustina, L., \& Noviri (2013) dan penelitian Elma Muncar Aditya dan Christian Budi Santoso (2012), EPS berpengaruh signifikan terhadap harga saham.

\subsection{Net Profit Margin}

Net Profit Margin (NPM) menurut Gitman, L. J., \& Zutter (2015:129) merupakan rasio antara laba bersih setelah pajak dengan penjualan bersih. NPM digunakan untuk mengukur besarnya laba bersih yang dicapai dari sejumlah penjualan tertentu, rasio ini yang umumnya dipakai dibandingkan dengan marjin laba kotor dan marjin laba operasi, mengingat laba yang dihasilkan adalah laba bersih perusahaan.

Rasio ini sangat baik bagi pemilik saham karena rasio tersebut menghitung sejauh mana kemampuan perusahaan menghasilkan laba bersih pada tingkat penjualan tertentu. Semakin besar NPM, maka kinerja perusahaan akan semakin produktif, sehingga akan meningkatkan kepercayaan investor untuk menanamkan modalnya pada perusahaan tersebut. Sebaliknya, jika rasio ini semakin turun maka kemampuan perusahaan dalam mendapatkan laba melalui penjualan dianggap cukup rendah. Perhitungan NPM dapat dirumuskan sebagai berikut :

$$
N P M=\frac{\text { Laba bersih setelah pajak }}{\text { Total Penjualan }} \times 100
$$

Menurut penelitian yang dilakukan oleh Watung, R. W., \& Ilat (2016) dan Edhi Asmirantho dan Elif Yuliawati (2015) menyatakan bahwa NPM berpengaruh terhadap harga saham.

\subsection{Suku Bunga Bank Indonesia}

Menurut hasil penelitian Selamet Riyadi (2014) Suku bunga Bank Indonesia adalah suku bunga dengan tenor satu bulan yang diumumkan oleh Bank Indonesia secara periodik untuk jangka waktu tertentu yang berbentuk sinyal. Bank Indonesia melakukan penguatan kerangka operasi moneter dengan mengeluarkan suku bunga kebijakan baru yaitu BI 7-Days Reverse Repo Rate. Penurunan BI Rate secara otomatis akan memicu penurunan tingkat suku bunga deposito maupun suku bunga kredit perbankan menurut Salim, A., \& Chrisnawati (2013) sehingga dapat disimpulkan bahwa semakin 
besar kenaikan Suku bunga BI, dapat menambahkan tingkat pengembalian yang diinvestasikan.

Tabel 1: Perkembangan BI Rate

\begin{tabular}{|c|c|}
\hline Tahun & $\begin{array}{c}\text { Rata - Rata BI Rate } \\
\text { Per Tahun }\end{array}$ \\
\hline 2012 & 5,77 \\
\hline 2013 & 6,48 \\
\hline 2014 & 7,54 \\
\hline 2015 & 7,52 \\
\hline 2016 & 6,75 \\
\hline 2017 & 6,78 \\
\hline
\end{tabular}

Sumber : www.bi.go.id

Menurut Penelitian yang dilakukan oleh Mulyani (2014) dan penelitian Kewal (2012) suku bunga Bank Indonesia berpengaruh negatif terhadap Harga saham.

\section{Metode Penelitian}

Penelitian ini menggunakan metode analisis kuantitatif. Dalam metode analisis kuantitatif, data yang digunakan berbentuk angka dalam proses pengelolahan data. Dalam mengelolah data, penelitian ini menggunakan sofware E-Views 9.0 untuk melakukan pengujian signifikasi analisis regresi data panel.

Populasi perusahaan dalam kelompok JII sebanyak 52 perusahaan, namun berdasarkan kriteria sampel diperoleh 10 perusahaan yang dijadikan sebagai sampel penelitian. Sampel yang digunakan yaitu Perusahaan dalam kelompok Jakarta Islamic Index di Bursa Efek Indonesia (BEI) pada periode 2012-2017. Teknik pengambilan sampel menggunakan metode purposive sampling yaitu pengambilan sampel dengan menggunakan kriteria-kriteria tertentu yang telah ditetapkan dalam penelitian. Kriteria pemilsampel yang akan diteliti adalah:

1. Perusahaan dalam kelompok Jakarta Islamic Index (JII) yang terdaftar pada Bursa Efek Indonesia pada periode 2012-2017.

2. Perusahaan dalam kelompok Jakarta Islamic Index (JII) yang terdaftar pada Bursa Efek Indonesia yang memiliki nilai transaksi terbesar di pasar regular dalam tahun penelitian. 3. Perusahaan yang terdaftar secara konsisten dalam kelompok Jakarta Islamic Index (JII) selama periode 2012-2017.

Berikut ini daftar Perusahaan Jakarta Islamic Index yang memiliki kriteria sesuai dengan penelitian adalah sebagai berikut :
Tabel 2: Daftar Sampel Penelitian

\begin{tabular}{|c|l|l|}
\hline No. & $\begin{array}{c}\text { Kode } \\
\text { Saham }\end{array}$ & \multicolumn{1}{|c|}{ Nama Perusahaan } \\
\hline 1. & AALI & Astra Agro Lestari Tbk \\
\hline 2. & ADRO & Adaro Energy Tbk \\
\hline 3. & AKRA & AKR Corporindo Tbk \\
\hline 4. & ASII & Astra Internasional Tbk \\
\hline 5. & INDF & $\begin{array}{l}\text { Indofood Sukses } \\
\text { Makmur Tbk }\end{array}$ \\
\hline 6. & KLBF & Kalbe Farma Tbk \\
\hline 7. & LPKR & Lippo Karawaci Tbk \\
\hline 8. & LSIP & $\begin{array}{l}\text { PP London Sumatera } \\
\text { Tbk }\end{array}$ \\
\hline 9. & TLKM & $\begin{array}{l}\text { Telekomunikasi } \\
\text { Indonesia Tbk }\end{array}$ \\
\hline 10. & UNVR & Unilever Indonesia Tbk \\
\hline
\end{tabular}

Sumber: www.idx.co.id data diolah

Metode pengumpulan data yang digunakan dalam penelitian ini adalah metode dokumentasi yaitu merupakan pengumpulan data sekunder yang diperoleh dari dokumen yang memiliki keterkaitan dengan

penelitian, seperti laporan keuangan perusahaan yang terdapat di Bursa Efek Indonesia (BEI).

\section{Hasil Penelitian dan Diskusi}

Pada penelitian ini, variabel-variabel yang dibahas yaitu variabel bebas (independen) yang terdiri dari earning per share, net profit margin dan suku bunga BI, serta variabel terikat (dependen) yaitu harga saham.

Adapun data earning per share pada perusahaan yang terdaftar dalam Jakarta Islamic Index adalah sebagai berikut:

Tabel 3 : Data Earning Per Share pada Perusahaan yang Terdaftar dalam Jakarta Islamic Index periode 2012-2017

\begin{tabular}{|c|c|c|c|c|c|c|}
\hline $\begin{array}{c}\text { Kode } \\
\begin{array}{c}\text { Perusah } \\
\text { aan }\end{array}\end{array}$ & \multicolumn{7}{|c|}{ Earning Per Share } \\
\cline { 2 - 7 } & $\mathbf{2 0 1 2}$ & $\mathbf{2 0 1 3}$ & $\mathbf{2 0 1 4}$ & $\mathbf{2 0 1 5}$ & $\mathbf{2 0 1 6}$ & $\mathbf{2 0 1 7}$ \\
\hline AALI & $\begin{array}{c}1,53 \\
1\end{array}$ & $\begin{array}{c}1,14 \\
4\end{array}$ & $\begin{array}{c}1,59 \\
0\end{array}$ & 393 & $\begin{array}{c}1,13 \\
8\end{array}$ & $\begin{array}{c}1,04 \\
4\end{array}$ \\
\hline ADRO & $\begin{array}{c}108 . \\
80\end{array}$ & $\begin{array}{c}88.7 \\
0\end{array}$ & $\begin{array}{c}69.1 \\
7\end{array}$ & $\begin{array}{c}65.7 \\
4\end{array}$ & $\begin{array}{c}140 . \\
56\end{array}$ & 204 \\
\hline AKRA & 168 & $\begin{array}{c}167 . \\
04\end{array}$ & $\begin{array}{c}206 . \\
99\end{array}$ & $\begin{array}{c}262 . \\
36\end{array}$ & $\begin{array}{c}253 . \\
22\end{array}$ & $\begin{array}{c}254 . \\
40\end{array}$ \\
\hline ASII & 480 & $\begin{array}{c}479 . \\
63\end{array}$ & $\begin{array}{c}473 . \\
80\end{array}$ & $\begin{array}{c}357 . \\
31\end{array}$ & $\begin{array}{c}374 . \\
37\end{array}$ & $\begin{array}{c}466 . \\
39\end{array}$ \\
\hline
\end{tabular}




\begin{tabular}{|c|c|c|c|c|c|c|}
\hline INDF & 371 & $\begin{array}{c}285 . \\
16\end{array}$ & $\begin{array}{c}442 . \\
50\end{array}$ & $\begin{array}{c}338 . \\
02\end{array}$ & $\begin{array}{c}472 . \\
02\end{array}$ & $\begin{array}{c}373 . \\
29\end{array}$ \\
\hline KLBF & 37 & $\begin{array}{c}37.8 \\
0\end{array}$ & $\begin{array}{c}44.0 \\
5\end{array}$ & $\begin{array}{c}42.7 \\
6\end{array}$ & $\begin{array}{c}49.0 \\
6\end{array}$ & $\begin{array}{c}37.9 \\
6\end{array}$ \\
\hline LPKR & $\begin{array}{c}46.4 \\
8\end{array}$ & $\begin{array}{c}69.0 \\
1\end{array}$ & $\begin{array}{c}135 . \\
85\end{array}$ & $\begin{array}{c}44.3 \\
8\end{array}$ & $\begin{array}{c}53.1 \\
8\end{array}$ & $\begin{array}{c}37.4 \\
5\end{array}$ \\
\hline LSIP & \multirow{2}{*}{164} & $\begin{array}{c}112 . \\
78\end{array}$ & $\begin{array}{c}134 . \\
36\end{array}$ & $\begin{array}{c}91.3 \\
6\end{array}$ & $\begin{array}{c}87.0 \\
4\end{array}$ & $\begin{array}{c}93.7 \\
4\end{array}$ \\
\hline TLKM & \multirow{2}{*}{133} & $\begin{array}{c}140 . \\
92\end{array}$ & $\begin{array}{c}145 . \\
22\end{array}$ & $\begin{array}{c}153 . \\
66\end{array}$ & $\begin{array}{c}171 . \\
93\end{array}$ & $\begin{array}{c}177 . \\
80\end{array}$ \\
\hline UNVR & 634 & $\begin{array}{c}701 . \\
52\end{array}$ & $\begin{array}{c}752 . \\
10\end{array}$ & $\begin{array}{c}766 . \\
95\end{array}$ & $\begin{array}{c}835 . \\
00\end{array}$ & $\begin{array}{c}918 . \\
03\end{array}$ \\
\hline
\end{tabular}

Sumber: www.idx.co.id data diolah

Grafik 1 :Data Perkembangan Earning Per Share pada Perusahaan yang Terdaftar dalam Jakarta Islamic Index Periode 2012-2017

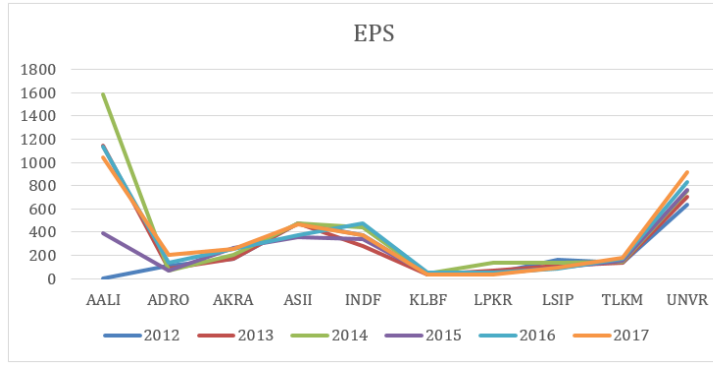

Dari grafik 1 di atas menunjukkan bahwa perkembangan earning per share pada perusahaan yang terdaftar dalam Jakarta Islamic Index pada periode 2012-2017 tidak banyak mengalami perubahan kenaikan maupun penurunan. EPS terbesar berada pada tahun 2014 sebesar 1,590 yaitu pada perusahaan Astra Agro Lestari Tbk, hal ini juga menunjukkan bahwa perusahaan ini memiliki nilai pasar yang cukup tinggi dibandingkan perusahaan JII lainnya. Sedangkan earning per share terendah berada pada perusahaan PT Kalbe Farma Tbk sebesar 37 di tahun 2012.

Data net profit margin pada perusahaan yang terdaftar dalam Jakarta Islmic Index :

\section{Tabel 4}

Data Net Profit Margin pada Perusahaan yang Terdaftar dalam Jakarta Islamic Index periode 2012-2017

\begin{tabular}{|c|c|c|c|c|c|c|}
\hline \multirow{3}{*}{$\begin{array}{c}\text { Kode } \\
\begin{array}{c}\text { Perusaha } \\
\text { an }\end{array}\end{array}$} & $\begin{array}{c}\mathbf{2 0 1} \\
\mathbf{2}\end{array}$ & $\begin{array}{c}\mathbf{2 0 1} \\
\mathbf{3}\end{array}$ & $\begin{array}{c}\mathbf{2 0 1} \\
\mathbf{4}\end{array}$ & $\begin{array}{c}\mathbf{2 0 1} \\
\mathbf{5}\end{array}$ & $\begin{array}{c}\mathbf{2 0 1} \\
\mathbf{6}\end{array}$ & $\begin{array}{c}\mathbf{2 0 1} \\
\mathbf{7}\end{array}$ \\
\hline AALI & $\begin{array}{c}21.7 \\
9\end{array}$ & $\begin{array}{c}15.0 \\
1\end{array}$ & $\begin{array}{c}16.0 \\
8\end{array}$ & 5.33 & $\begin{array}{c}14.9 \\
7\end{array}$ & $\begin{array}{c}11.8 \\
3\end{array}$ \\
\hline ADRO & $\begin{array}{c}10.0 \\
8\end{array}$ & 6.98 & 5.51 & 5.63 & $\begin{array}{c}13.5 \\
0\end{array}$ & $\begin{array}{c}16.4 \\
6\end{array}$ \\
\hline AKRA & 2.86 & 2.76 & 3.52 & 5.36 & 6.88 & 8.26 \\
\hline
\end{tabular}

\begin{tabular}{|l|c|c|c|c|c|c|}
\hline ASII & $\begin{array}{c}12.0 \\
9\end{array}$ & $\begin{array}{c}11.5 \\
0\end{array}$ & $\begin{array}{c}10.9 \\
7\end{array}$ & 8.48 & $\begin{array}{c}10.1 \\
1\end{array}$ & $\begin{array}{c}11.2 \\
4\end{array}$ \\
\hline INDF & 9.52 & 5.92 & 8.09 & 5.79 & 7.89 & 8.12 \\
\hline KLBF & $\begin{array}{c}13.0 \\
2\end{array}$ & $\begin{array}{c}12.3 \\
1\end{array}$ & $\begin{array}{c}12.2 \\
1\end{array}$ & $\begin{array}{c}11.5 \\
0\end{array}$ & $\begin{array}{c}12.1 \\
3\end{array}$ & $\begin{array}{c}12.0 \\
1\end{array}$ \\
\hline LPKR & $\begin{array}{c}21.4 \\
7\end{array}$ & $\begin{array}{c}23.8 \\
9\end{array}$ & $\begin{array}{c}26.9 \\
0\end{array}$ & $\begin{array}{c}11.4 \\
9\end{array}$ & $\begin{array}{c}11.6 \\
5\end{array}$ & $\begin{array}{c}11.5 \\
4\end{array}$ \\
\hline LSIP & $\begin{array}{c}19.7 \\
7\end{array}$ & $\begin{array}{c}18.5 \\
9\end{array}$ & $\begin{array}{c}19.3 \\
9\end{array}$ & $\begin{array}{c}14.8 \\
8\end{array}$ & $\begin{array}{c}15.4 \\
1\end{array}$ & $\begin{array}{c}17.8 \\
9\end{array}$ \\
\hline TLKM & $\begin{array}{c}31.4 \\
1\end{array}$ & $\begin{array}{c}24.4 \\
6\end{array}$ & $\begin{array}{c}23.9 \\
1\end{array}$ & $\begin{array}{c}22.7 \\
5\end{array}$ & $\begin{array}{c}25.0 \\
8\end{array}$ & $\begin{array}{c}26.8 \\
2\end{array}$ \\
\hline UNVR & $\begin{array}{c}17.7 \\
2\end{array}$ & $\begin{array}{c}17.4 \\
0\end{array}$ & $\begin{array}{c}17.1 \\
7\end{array}$ & $\begin{array}{c}16.0 \\
4\end{array}$ & $\begin{array}{c}15.9 \\
6\end{array}$ & \\
\hline
\end{tabular}

Sumber: www.idx.co.id data diolah

Grafik 2: Data Perkembangan Net Profit Margin pada Perusahaan yang Terdaftar dalam Jakarta Islamic Index Periode 2012-2017

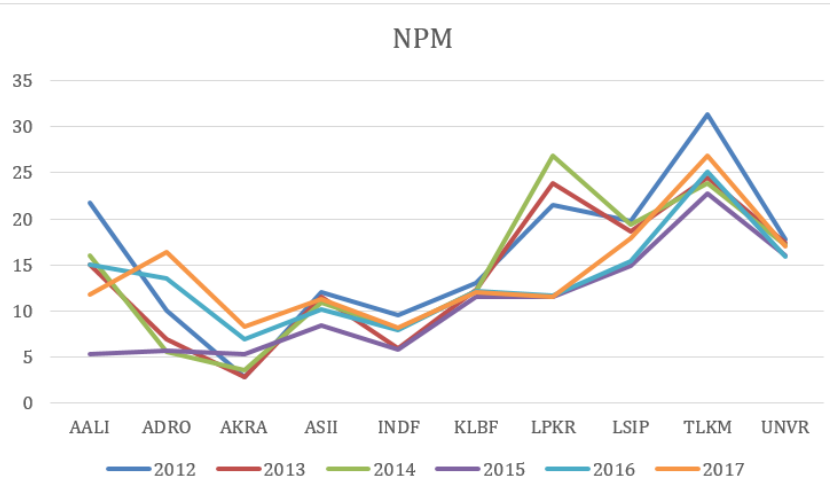

Dari grafik 2 di atas menunjukkan bahwa net profit margin pada perusahaan Jakarta Islamic Index periode 2012- 2017 cenderung berubah-ubah (fluktuatif). Tingkat NPM terbesar terdapat pada perusahaan PT Telekomunikasi Indonesia Tbk di tahun 2012 sebesar $31,41 \%$. Dengan demikian, perusahaan

Dari grafik 2 di atas menunjukkan bahwa net profit margin pada perusahaan Jakarta Islamic Index periode 2012- 2017 cenderung berubahubah (fluktuatif). Tingkat NPM terbesar terdapat pada perusahaan PT Telekomunikasi Indonesia Tbk di tahun 2012 sebesar 31,41\%. Dengan demikian, perusahaan tersebut dapat dikatakan sangat efisien dalam mengeluarkan biaya- biaya untuk kegiatan operasinya dan berhasil mengendalikan beban usahanya. Tingkat NPM terendah terdapat pada perusahaan PT AKR Corporindo Tbk pada tahun 2013 yaitu sebesar $2,76 \%$. 
Suku bunga bank Indonesia adalah suku bunga kebijakan yang mencerminkan sikap kebijakan moneter yang ditetapkan oleh bank Indonesia dan diumumkan kepada public (www.bi.go.id). Penurunan suku bunga bank Indonesia secara otomatis akan memicu penurunan tingkat suku bunga deposito maupun suku bunga kredit perbankan (Salim \& Chrisnawati, 2013). Berikut adalah data Suku bunga Bank Indonesia tahun 2012-2017 :

Tabel 5: Data Suku Bunga Bank Indonesia Tahun 2012-2017

\begin{tabular}{|c|c|}
\hline Tahun & $\begin{array}{c}\text { Rata - Rata BI Rate } \\
\text { Per Tahun }\end{array}$ \\
\hline 2012 & 5,77 \\
\hline 2013 & 6,48 \\
\hline 2014 & 7,54 \\
\hline 2015 & 7,52 \\
\hline 2016 & 6,75 \\
\hline 2017 & 6,78 \\
\hline
\end{tabular}

Sumber: www.bi.go.id

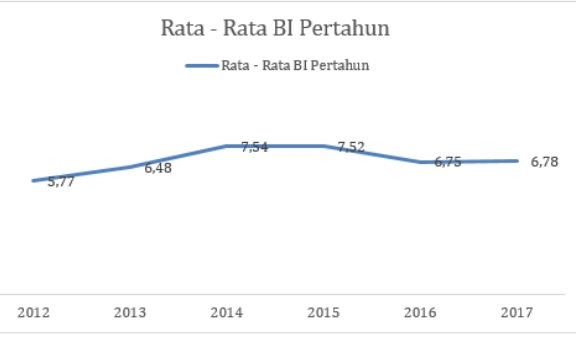

Grafik 3 : Data Perkembangan Suku Bunga

Bank Indonesia pada Periode 2012-2017

Dari grafik 3 diatas menunjukkan bahwa suku bunga BI pada periode 2012- 2017 cenderung mengalami kenaikan. Tingkat suku bunga tertinggi terdapat di tahun 2014 sebesar $7.54 \%$. Hal tersebut memungkinkan pada tahun tersebut investor lebih berminat berinvestasi di pasar uang. Sebaliknya, tingkat suku bunga terendah terdapat pada tahun 2012, sehingga memungkinkan pada tahun tersebut investor lebih berminat di pasar modal.

Harga saham merupakan harga yang terjadi di bursa pada waktu tertentu. harga saham bisa berubah naik ataupun turun dalam hitungan waktu yang begitu cepat. Pergerakan harga saham tersebut ditentukan oleh permintaan dan penawaran atas saham-saham. Adapun data harga saham pada sektor perusahaan yang terdaftar dalam Jakarta Islamic Index adalah sebagai berikut:
Tabel 6: Data Harga Saham pada

Perusahaan yang Terdaftar dalam Jakarta Islamic Index periode 2012-2017

\begin{tabular}{|c|c|c|c|c|c|c|}
\hline \multirow{3}{*}{$\begin{array}{c}\text { Kode } \\
\text { Perusah } \\
\text { aan }\end{array}$} & $\mathbf{2 0 1 2}$ & $\mathbf{2 0 1 3}$ & $\mathbf{2 0 1 4}$ & $\mathbf{2 0 1 5}$ & $\mathbf{2 0 1 6}$ & $\mathbf{2 0 1 7}$ \\
\cline { 2 - 7 } & & & & & & \\
\hline AALI & 17,9 & 20,4 & 24,2 & 15,8 & 16,7 & 13,1 \\
& 61 & 63 & 50 & 50 & 75 & 50 \\
\hline ADRO & 1,59 & 1,09 & 1,04 & 515 & 1,69 & 1,86 \\
& 0 & 0 & 0 & & 5 & 0 \\
\hline AKRA & 4,15 & 4,37 & 4,12 & 7,17 & 6,00 & 6,35 \\
& 0 & 5 & 0 & 5 & 0 & 0 \\
\hline ASII & 7,35 & 6,42 & 7,42 & 6,00 & 8,27 & 8,30 \\
& 0 & 5 & 5 & 0 & 5 & 0 \\
\hline INDF & 5,85 & 6,60 & 6,75 & 5,17 & 7,92 & 7,62 \\
& 0 & 0 & 0 & 5 & 5 & 5 \\
\hline KLBF & 1,03 & 1,25 & 1,83 & 1,32 & 1,51 & 1.69 \\
& 0 & 0 & 0 & 0 & 5 & 0 \\
\hline LPKR & 1,03 & 950 & 1,02 & 1,03 & 720 & 488 \\
& 0 & & 0 & 5 & & \\
\hline LSIP & 2,20 & 1,65 & 1,89 & 1,32 & 1,74 & 1,42 \\
& 0 & 5 & 0 & 0 & 0 & 0 \\
\hline TLKM & 9,70 & 2,27 & 2,86 & 3,10 & 3,98 & 4,44 \\
& 0 & 5 & 5 & 5 & 0 & 0 \\
\hline UNVR & 22,0 & 28,5 & 32,3 & 37,0 & 38,8 & 55,9 \\
& 50 & 50 & 00 & 00 & 00 & 00 \\
\hline
\end{tabular}

Sumber: www.yahoo.com

Grafik 4 : Data Perkembangan Harga Saham pada Sektor Perusahaan yang Terdaftar dalam Indeks Saham Syariah Indonesia Periode 20122017

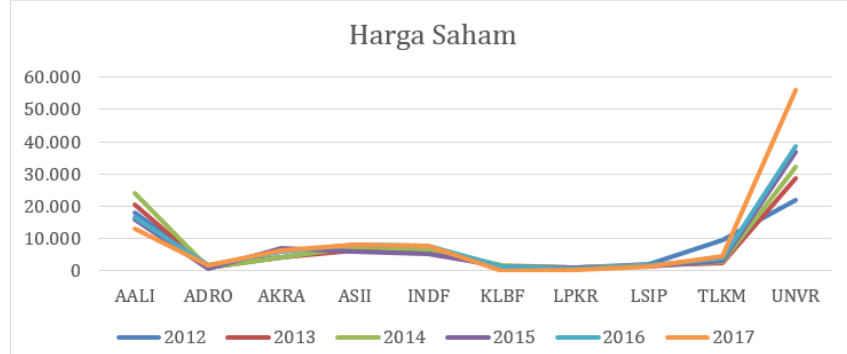

Grafik 4 di atas menunjukkan bahwa perkembangan harga saham pada perusahaan yang terdaftar dalam Jakarta Islamic Index periode 2012-2017 cenderung stabil. Tingkat harga saham terbesar berada pada tahun 2017 sebesar Rp 55.900 yaitu pada perusahaan Unilever Indonesia Tbk. Hal ini menunjukkan bahwa laba bersih perusahaan yang berada di perusahaan ini meningkat sehingga dapat mengakibatkan kenaikan terhadap harga saham perusahaan. Sedangkan tingkat harga saham terendah berada pada tahun 2016 sebesar Rp 515 yaitu pada perusahaan PT Adaro Energy Tbk. Hal ini dapat disebabkan karena rasio keuangan dan juga citra perusahaan di perusahaan Adaro Energy Tbk tersebut. 
Pemilihan model regresi data panel.Dalam penelitian ini dilakukan pemilihan model regresi data panel dengan: Uji Chow dan Uji Hausman, setelah diakukan kedua uji tersebut terbukti bahwa Random Effect yang lebih tepat digunakan dalam penelitian ini, dibandingkan Common Effect ataupun Fixed Effect, kemudian ditentukan model regresi yang tepat, maka dapat diperoleh hasil persamaan regresi yaitu:

Harga Saham $=2,024998+0.769240$ EPS + 0.250830 NPM - 0.206292 BUNGA

Uji Asumsi Klasik.

Uji Normalitas: Digunakan untuk menguji model yang diperoleh berdistribusi normal atau tidak.

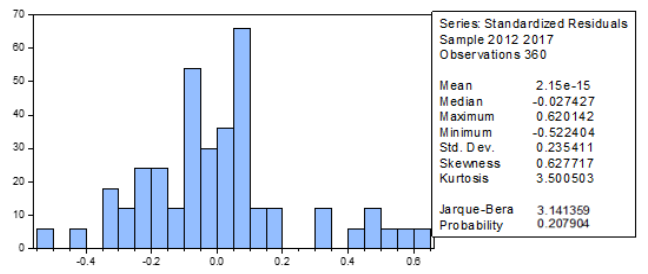

Dari gambar di atas dapat dilihat bahwa nilai jarque-bera yaitu sebesar 3.141359 lebih besar dari 2 dan nilai probabilitasnya lebih besar dari $\alpha$ $=5 \%$ yaitu sebesar 0,207904 maka dapat disimpulkan bahwa data dalam penelitian ini terdistribusi normal.

\section{Uji Autokorelasi:}

Uji autokorelasi bertujuan untuk mengetahui adanya hubungan antara residual satu observasi dengan observasi lainnya. Untuk mengetahui adanya gejala autokerelasi, yaitu dengan cara melihat besarnya nilai dari uji D- W (Durbin Watson) atau dengan menggunakan uji BreuschGodfrey. Berikut merupakan hasil uji autokorelasi dalam penelitian ini:

\section{Hasil Uji Autokorelasi}

Breusch-Godfrey Serial Correlation LM Test:

\begin{tabular}{llll}
\hline & & & \\
F-statistic & 7.697337 & Prob. F(3,53) & 0.0502 \\
Obs*R-squared & 18.20849 & Prob. Chi-Square(3) & 0.0644
\end{tabular}

Sumber: Hasil Olah Data E-Views 9.

Dalam tabel diatas dapat dilihat bahwa probabilitas chi-square sebesar 0,0644 lebih besar dari tingkat signifikansi $\alpha=5 \%$. Jadi dapat disimpulkan bahwa tidak terdapat autokorelasi dalam penelitian ini.

\section{Uji Multikolinieritas}

Uji multikolonieritas bertujuan untuk mengetahui apakah dalam model regresi ditemukanadanya korelasi antar variabel bebas. Model regresi yang baik tidak menghendaki adanya korelasiantar variabel independen.

\section{Hasil Uji Multikolonieritas}

\begin{tabular}{|c|c|c|c|}
\hline & LOG(EPS) & NPM & BUNGA \\
\hline LOG(EPS) & 1.000000 & -0.010770 & -0.008793 \\
\hline NPM & -0.010770 & 1.000000 & -0.167712 \\
\hline BUNGA & -0.008793 & -0.167712 & 1.000000 \\
\hline
\end{tabular}

Sumber: Hasil Olah Data E-Views 9.

Berdasarkan hasil tabel di atas dapat dilihat nilai koefisien korelasi antar variabel diatas menunjukkan bahwa nilai koefisien dari masingmasing variabel EPS, NPM dan suku bunga BI dibawah 0,80. Maka dapat disimpulkan. Penelitian ini terbebas dari masalah multikolineritas.

\section{Uji Heteroskedatisitas}

Uji Heteroskedastisitas bertujuan untuk menguji terjadi atau tidaknya ketidaksamaan varian dari residual satu pengamatan ke pengamatan lainnya dalam suatu model regresi. Berikut merupakan hasil uji heteroskedastisitas dalam penelitian ini:

\section{Uji Heteroskedastisitas (Breush Pagan Godfrey)}

\begin{tabular}{|l|c|c|c|}
\hline \multicolumn{4}{|c|}{ Heteroskedasticity Test: Breusch-Pagan-Godfrey } \\
\hline F-statistic & 2.352855 & Prob. F(3,56) & 0.0819 \\
\hline Obs*R-squared & 6.716199 & $\begin{array}{c}\text { Prob. Chi- } \\
\text { Square(3) }\end{array}$ & 0.0815 \\
\hline $\begin{array}{l}\text { Scaled } \\
\text { explained SS }\end{array}$ & $\begin{array}{c}\text { Prob. Chi- } \\
\text { Square(3) }\end{array}$ & 0.1828 \\
\hline
\end{tabular}

Sumber: Hasil Pengolahan Data Eviews 9

Dari tabel di atas dapat dilihat bahwa probabilitas masing-masing variabel independen, yaitu EPS, NPM dan Suku Bunga Bank Indonesia lebih besar dari tingkat signifikansi alpha $(0,05)$. Probabilitas masingmasing variabel independen secara berturutturut, yaitu sebesar 0,$0819 ; 0,0815 ; 0.1828$. Maka dalam penelitian ini tidak terdapat heteroskedastisitas. 


\section{Model Regresi Data Panel}

Berikut ini adalah tabel model data regresi data panel

Dependent Variable: LOG(HARGA)

Method: Panel EGLS (Cross-section random effects)

Date: 10/22/18 Time: 18:13

Sample: 20122017

Periods included: 6

Cross-sections included: 10

Total panel (balanced) observations: 60

Swamy and Arora estimator of component variances

\begin{tabular}{ccccc}
\hline Variable & Coefficient & Std. Error & t-Statistic & Prob. \\
& & & & \\
C & 2.024998 & 0.281727 & 7.187792 & 0.0000 \\
LOG(EPS) & 0.769240 & 0.111308 & 6.910900 & 0.0000 \\
NPM & 0.250830 & 0.522850 & 0.479736 & 0.0333 \\
BUNGA & -2.206292 & 2.546617 & -0.866362 & 0.3900 \\
& & & & \\
\hline
\end{tabular}

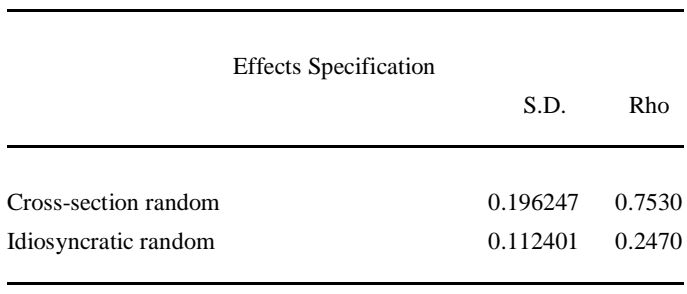

Weighted Statistics

\begin{tabular}{llll}
\hline & & & \\
R-squared & 0.489827 & Mean dependent var & 0.823102 \\
Adjusted R-squared & 0.462496 & S.D. dependent var & 0.165955 \\
S.E. of regression & 0.121670 & Sum squared resid & 0.828996 \\
F-statistic & 17.92221 & Durbin-Watson stat & 1.803833 \\
Prob(F-statistic) & 0.000000 & & \\
& & &
\end{tabular}

Unweighted Statistics

R-squared $\quad 0.779544$ Mean dependent var 3.615109

Sum squared resid $\quad 3.484073$ Durbin-Watson stat 0.429202

\section{Sumber: Hasil Olah Data E-Views 9}

Berdasarkan tabel di atas, menunjukkan bahwa variabel independen yaitu earning per share dan net profit margin mempunyai pengaruh yang signifikan terhadap variabel dependen yaitu harga saham karena probabilitas dibawah 0,05 (Prob < 0,05). Sedangkan variabel independen suku bunga BI tidak mempunyai pengaruh yang signifikan terhadap variabel dependen yaitu harga saham karena probabilitas diatas 0,05 (Prob > 0,05). Hasil Adj R-squared sebesar 0.462496 atau $46,25 \%$ merupakan nilai yang menunjukkan pengaruh variabel independen terhadap variabel dependen. Sisanya sebesar 53,75\% dipengaruhi oleh faktor lain.

\section{Uji t Parsial}

Uji $t$ atau uji parsial digunakan untuk mengetahui apakah ada pengaruh variabel independen secara parsial atau individu terhadap variabel dependen. Suatu variabel independen dapat dikatakan memiliki pengaruh signifikan terhadap variabel dependen jika nilai t hitung lebih besar dari t tabel ( $t$ hitung $>t$ tabel) atau jika nilai dari probabilitas masing-masing variabel bebas p-value lebih kecil dari $\alpha(\mathrm{p}$-value $<\alpha)$.

Harga Saham $=2,024998+0.769240$ EPS + 0.250830 NPM - 0.206292 BUNGA

\section{Hasil Uji t (Parsial)}

Dependent Variable: LOG(HARGA)

Method: Panel EGLS (Cross-section random effects)

Date: 10/22/18 Time: 18:13

Sample: 20122017

Periods included: 6

Cross-sections included: 10

Total panel (balanced) observations: 60

Swamy and Arora estimator of component variances

\begin{tabular}{crrrr}
\hline Variable & Coefficient & Std. Error & t-Statistic & Prob. \\
\hline & & & & \\
C & 2.024998 & 0.281727 & 7.187792 & 0.0000 \\
LOG(EPS) & 0.769240 & 0.111308 & 6.910900 & 0.0000 \\
NPM & 0.250830 & 0.522850 & 0.479736 & 0.0333 \\
BUNGA & -2.206292 & 2.546617 & -0.866362 & 0.3900
\end{tabular}

Sumber: Hasil Pengolahan Data Eviews 9

Hipotesis yang digunakan dalam uji $\mathbf{t}$ adalah sebagai berikut:

\section{Earning Per Share (EPS)}

$\mathrm{H}_{0}$ : EPS tidak berpengaruh terhadap harga saham

$\mathrm{H}_{2}$ : EPS berpengaruh terhadap harga saham

Untuk variabel EPS diperoleh nilai t-statistik sebesar 6.910900 dengan nilai probabilitas 0.0000 lebih kecil dari tingkat signifikan sebesar $5 \%$ (Prob < 0,05), maka dapat disimpulkan $\mathrm{H}_{0}$ ditolak dan $\mathrm{H}_{2}$ diterima. Sehingga dapat dijelaskan bahwa variabel EPS berpengaruh terhadap harga saham. Artinya, EPS yang meningkat menunjukkan bahwa jumlah laba yang dibagikan kepada investor semakin besar, 
sehingga dengan meningkatnya EPS ini akan menarik investor untuk membeli saham, dengan permintaan saham yang meningkat maka harga saham perusahaan juga akan ikut meningkat. Hasil penelitian ini konsisten dengan teori yang dikemukakan oleh Gitman, L. J., \& Zutter (2015:130) yang menyatakan EPS merupakan jumlah rupiah yang diperoleh selama periode atas nama setiap lembar saham biasa yang beredar. Semakin tinggi EPS maka harga saham tersebut akan ikut naik. Hasil ini pun sejalan dengan penelitian yang dilakukan oleh Agustina, L., \& Noviri (2013) yang menyatakan bahwa EPS berpengaruh positif signifikan terhadap harga saham pada index LQ45 tahun 2010 dan penelitian Safitri (2013) yang menyatakan bahwa EPS berpengaruh positif signifikan terhadap harga saham dalam kelompok JII tahun 20082011. Namun hal ini bertolak belakang dengan penelitian yang dilakukan oleh Pande Widya Rahmadewi (2018) yang menyatakan bahwa EPS tidak berpengaruh terhadap harga saham.

\section{Net Profit Margin}

$\mathrm{H}_{0}$ : NPM tidak berpengaruh terhadap harga saham

$\mathrm{H}_{2}$ : NPM berpengaruh terhadap harga saham Untuk variabel NPM diperoleh nilai t-statistik sebesar 0.479736 dengan nilai probabilitas 0.0333, lebih kecil dari tingkat signifikan sebesar $5 \%$ (Prob < 0,05), maka dapat disimpulkan $\mathrm{H}_{0}$ ditolak dan $\mathrm{H}_{2}$ diterima. Sehingga dapat dijelaskan bahwa variabel NPM berpengaruh terhadap harga saham. Artinya, semakin tinggi laba bersih suatu perusahaan, maka saham perusahaan tersebut akan semakin diminati oleh investor, sehingga akan meningkatkan harga saham perusahaan Hasil ini konsisten dengan teori yang dikemukakan oleh Gitman, L. J., \& Zutter (2015:129) yang menyatakan bahwa NPM adalah ukuran keberhasilan perusahaan yang sering dikutip sehubungan dengan pendapatan dari penjualan. Semakin baik perusahaan dalam menghasilkan laba, maka permintaan terhadap saham perusahaan tersebut akan meningkat sehingga akan meningkatkan harga saham nya. Hasil penelitian ini juga sejalan dengan penelitian yang dilakukan oleh Edhi Asmirantho dan Elif Yuliawati (2015) yang menyatakan bahwa NPM berpengaruh positif dan signifikan terhadap harga saham perusahaan manufaktur sub sektor makanan dan minuman dalam kemasan yang terdaftar di BEI tahun 2007-2013 dan Hutami (2012) yang menyatakan bahwa NPM berpengaruh positif signifikan terhadap harga saham industry manufaktur yang tercatat di BEI tahun 2006-2010. Namun hal ini tidak sesuai dengan penelitian yang dilakukan oleh Watung, R. W., \& Ilat (2016) yang menyatakan bahwa NPM tidak berpengaruh terhadap harga saham pada perusahaan asuransi yang terdaftar di BEI tahun 2011-2013.

3. Suku Bunga Bank Indonesia

$\mathrm{H}_{0}$ : BI Rate tidak berpengaruh terhadap harga saham

$\mathrm{H}_{1}$ : BI Rate berpengaruh terhadap harga saham

Untuk variabel BI Rate diperoleh nilai t-statistik sebesar -0.866362 dengan nilai probabilitas 0.3900 lebih besar dari tingkat signifikan sebesar $5 \%$ (Prob > 0,05), maka dapat disimpulkan $\mathrm{H}_{0}$ diterima dan $\mathrm{H}_{1}$ ditolak. Sehingga dapat disimpulkan bahwa variabel BI Rate tidak berpengaruh terhadap harga saham. Hasil penelitian ini sejalan dengan penelitian yang dilakukan oleh Dewi, S. P., \& Hidayat (2014) dan penelitian Ratih, D., Prihatini A. E. Saryadi (2014) yang menyatakan bahwa BI Rate tidak berpengaruh terhadap harga saham. Berbeda dengan pebelitian yang dilakukan oleh Selamet Riyadi (2014) yang menyatakan secara parsial tingkat suku bunga BI berpengaruh positif tidak signifikan terhadap harga saham.

\section{Uji F (Simultan)}

Uji $F$ atau uji simultan digunakan untuk mengetahui apakah model yang telah diestimasi layak digunakan untuk menjelaskan pengaruh variabel independen (bebas) terhadap variabel dependen (terikat). Di dalam penelitian ini hipotesis yang digunakan untuk Uji F (simultan) adalah :

$\mathrm{H}_{0}$ :Model regresi yang diestimasi tidak layak digunakan

$\mathrm{H}_{1}$ :Model regresi yang diestimasi layak digunakan

Ketentuan : Prob (F-statistik) $<5 \%$, maka $\mathrm{H}_{0}$ ditolak dan $\mathrm{H}_{1}$ diterima

Prob (F-statistik) > 5\%, maka $\mathrm{H}_{0}$ diterima dan $\mathrm{H}_{1}$ ditolak

Hasil Uji F (Simultan)

\begin{tabular}{|l|c|c|c|}
\hline R-squared & 0.489827 & $\begin{array}{l}\text { Mean } \\
\text { dependent var }\end{array}$ & 0.823102 \\
\hline $\begin{array}{l}\text { Adjusted R- } \\
\text { squared }\end{array}$ & 0.462496 & $\begin{array}{l}\text { S.D. dependent } \\
\text { var }\end{array}$ & 0.165955 \\
\hline $\begin{array}{l}\text { S.E. of } \\
\text { regression }\end{array}$ & 0.121670 & $\begin{array}{l}\text { Sum squared } \\
\text { resid }\end{array}$ & 0.828996 \\
\hline
\end{tabular}




\begin{tabular}{|l|c|c|c|c|}
\hline F-statistic & 17.92221 & \multicolumn{2}{|c|}{$\begin{array}{c}\text { Durbin-Watson } \\
\text { stat }\end{array}$} & 1.803833 \\
\hline $\begin{array}{l}\text { Prob(F- } \\
\text { statistic) }\end{array}$ & 0.000000 & & & \\
\hline
\end{tabular}

Berdasarkan hasil tabel 4.15 diperoleh nilai Prob (F-statistik) sebesar 0.000000 lebih kecil dari $5 \%(<0,05)$ yang artinya $\mathrm{H}_{0}$ ditolak dan $\mathrm{H}_{1}$ diterima. Jadi dapat disimpulkan bahwa EPS, NPM dan BI rate secara simultan berpengaruh signifikan terhadap harga saham. Hasil ini sesuai dari Penjelasan dari Gitman \& Zutter (2015:130) yang menyatakan bahwa EPS yang tinggi menandakan perusahaan yang bagus, sehingga perusahaan ini akan menarik investor untuk berinvestasi sehingga harga saham akan naik. Hal ini sama dengan NPM yang menurut Gitman \& Zutter (2015:130) perusahaan yang bagus memiliki NPM yang tinggi. Dalam penelitian ini secara parsial suku bunga bank Indonesia tidak mempunyai pengaruh terhadap harga saham karena nilai probabilitas sebesar 0,3900 $<0,05$. Tapi dapat disimpulkan berdasarkan hasil penelitian diperoleh uji F bahwa nilai Prob (Fstatistik) sebesar 0.000000 lebih kecil daripada $5 \%(<0,05)$. Yang artinya EPS, NPM dan BI rate secara simultan berpengaruh signifikan terhadap harga saham. Besarnya pengaruh secara simultan EPS, NPM, dan suku bunga Indonesia terhadap harga saham adalah sebesar $46,2 \%$.

\section{Uji Koefisien Determinasi $\left(\mathbf{R}^{2}\right)$}

Uji koefisien determinasi $\left(\mathrm{R}^{2}\right)$ digunakan untuk mengetahui kemampuan model regresi atau variabel independen (bebas) dalam menjelaskan variabel dependen (terikat) atau bisa dikatakan untuk melihat persentase pengaruh variabel independen terhadap variabel dependen. Berikut ini adalah hasil uji koefisien determinasi dengan menggunakan software $E$ views 9 .

\section{Hasil Uji Koefisien Determinasi $\left(\mathbf{R}^{\mathbf{2}}\right)$}

\begin{tabular}{|c|c|c|c|}
\hline R-squared & 0.489827 & $\begin{array}{c}\text { Mean } \\
\text { dependent var }\end{array}$ & 0.823102 \\
\hline $\begin{array}{l}\text { Adjusted R- } \\
\text { squared }\end{array}$ & 0.462496 & $\begin{array}{l}\text { S.D. dependent } \\
\text { var }\end{array}$ & 0.165955 \\
\hline $\begin{array}{l}\text { S.E. of } \\
\text { regression }\end{array}$ & 0.121670 & $\begin{array}{l}\text { Sum squared } \\
\text { resid }\end{array}$ & 0.828996 \\
\hline F-statistic & 17.92221 & $\begin{array}{l}\text { Durbin-Watson } \\
\text { stat }\end{array}$ & 1.803833 \\
\hline $\begin{array}{l}\text { Prob(F- } \\
\text { statistic) }\end{array}$ & 0.000000 & & \\
\hline
\end{tabular}

Berdasarkan tabel 4.16, nilai Adjusted $R$ squared sebesar 0.462496. Hal ini menunjukkan bahwa $46.2 \%$ variabel independen yaitu EPS, NPM dan Suku bunga BI secara simultan berpengaruh terhadap harga saham. Sedangkan sisanya $53,76 \%$ dipengaruhi oleh variabel independen lainnya yang diluar dari penelitian ini.

\section{Kesimpulan}

Berdasarkan hasil dan pembahasan dalam penelitian ini, maka dapat diambil kesimpulannya sebagai berikut:

1. Variabel earning per share dan net profit margin berpengaruh secara positif dan signifikan terhadap harga saham pada Perusahaan dalam kelompok Jakarta Islamic Indeks periode 2012-2017.

2. Variabel suku bunga Bank Indonesia tidak berpengaruh terhadap harga saham pada Perusahaan dalam kelompok Jakarta Islamic Indeks Indeks periode 2012-2017.

3. Earning per share, net profit margin dan suku bunga Bank Indonesia secara simultan berpengaruh positif dan signifikan terhadap harga saham pada Perusahaan dalam kelompok Jakarta Islamic Indeks periode 2012-2017.

Ditunjukkan dengan besarnya adjusted $\mathrm{R}$ squared $46,25 \%$.

Hasil penelitian ini diharapkan dapat memberikan kontribusi bagi perusahaan yang terdaftar dalam kelompok Jakarta Islamic Indeks. Perusahaan perusahaan dapat menggunakan hasil penelitian ini untuk pengambilan keputusan financial dan menetapkan kebijakan strategis dimasa yang akan datang agar menarik para investor. Variable dalam penelitian ini seperti EPS dan NPM yang merupakan rasio profitabilitas sering dilihat oleh investor untuk pengambilan keputusan dalam membeli saham, dapat diartikan bahwa ketika EPS dan NPM suatu perusahaan tinggi maka kinerja perusahaan bagus. Selain dua variable tersebut, para investor perlu melihat faktor eksternal perusahaaan seperti tingkat suku bunga dalam keputusannya dalam membeli saham.

\section{DAFTAR PUSTAKA}

Achmad Husaini. 2012. "Pengaruh Variabel Return On Asset, Returb On Equity, Net Profit Margin Dan Earning Per Share Terhadap Harga Saham Perusahaan." Jurnal Profit 6 nomor 1: 45-49.

Agustina, L., \& Noviri, S. 2013. "Pengaruh Return On Asset ( ROA ), Earning Per Share (EPS), Dan Tingkat Suku Bunga SBI Terhadap Harga Saham ( Studi Pada Indeks LQ45 Tahun 2010 ).” Jurnal 
Akuntansi 5 (1): 1-19.

Dewi, S. P., \& Hidayat, R. 2014. "Pengaruh Net Profit Margin Dan Return On Assets Terhadap Harga Saham Pada Perusahaan Otomotif Yang Terdaftar Di Bursa Efek Indonesia." Jurnal Ilmu Manajemen 1 (1): $1-10$.

Edhi Asmirantho dan Elif Yuliawati. 2015. "Pengaruh Dividen Per Share (DPS), Dividen Payout Ratio (DPR), Price To Book Value (PBV), Debt To Equity Ratio (DER), Net Profit Margin (NPM) Dan Return On Aset (ROA)Terhadap Harga Saham Pada Perusahaan Manufaktur Sub Sektor Makanan Dan Minuman Dalam Kemas." JIAFE Jurnal Ilmiah Akuntansi Fakultas Ekonomi 1 (2): 95-117.

Elma Muncar Aditya dan Christian Budi Santoso. 2012. "Analisis Pengaruh EPS, EVA Dan Cash Flow Terhadap Harga Saham Perusahaan Food and Beverage Yang Terdaftar Di BEI.” Jurnal Ekonomi dan Bisnis Indonesia 10 (1): 62-70.

Fahmi, I. 2014. Manajemen Keuangan Perusahaan Dan Pasar Modal. Jakarta: Mittra Wacana Media.

Gitman, L. J., \& Zutter, C. J. 2015. Principles of Managerial Finance. 14 th. Pearson.

Husnan, S., \& Pudjiastuti, E. 2015. Dasar-Dasar Manajemen Keuangan. Ketujuh. Yogyakarta: UPP STIM YKPN.

Hutami. 2012. "Effect of Dividend per Share, Return On Equity, and Net Profit Margin on the Stock Prices of Manufacturing Industry Companies That Are Listed on the Indonesia Stock Exchange Period 20062010." Nominal Journal 1(1): 104-123.

Kewal, S. S. 2012. "Pengaruh Inflasi, Suku Bunga, Kurs, Dan Pertumbuhan PDB Terhadap Indeks Harga Saham Gabungan.” Jurnal Economia 8 (1): 5364.

Mulyani, N. 2014. "Analisis Pengaruh Inflasi, Suku Bunga, Nilai Tukar Rupiah, Dan Produk Domestik Bruto Terhadap Jakarta Islamic Index." Jurnal Bisnis Dan Manajemen Eksekutif 1 (10)(1-13).

Pande Widya Rahmadewi, Nyoman Abundanti. 2018. "Pengaruh EPS, PER CR Dan ROE Terhadap Harga Saham Di Bursa Efek Indonesia." E-Jurnal Manajemen Unud 7 (4): 1-28.

Ratih, D., Prihatini A. E. Saryadi. 2014. "Effect of EPS, PER, DER, ROE on Stock Prices in Mining Sector Companies Listed on the
Indonesia Stock Exchange (IDX) for 20102012. Journal of Business Administration, Vol. 3, No. 1, Things 1-12." Journal of Business Administration 3(1): 1-12.

Safitri, A. L. 2013. "Pengaruh Earning Per Share , Price Earning Ratio, Return On Asset, Debt to Equity Ratio Dan Market Value Added." Jurnal Unes 2 (2): 1-8.

Salim, A., \& Chrisnawati, L. 2013. "Effect of Interest Rates and Inflation of Reference Bank." E-Jurnal Manajemen Dan Bisnis 1 (1): 1-15.

Selamet Riyadi. 2014. "Analisis Pengaruh Kinerja Keuangan, BI RATE Dan Earning Per Share Terhadap Harga Saham Bank BUMN Di BURSA EFEK INDONESIA (PERIODE 2008-2013)." Jurnal Wahana 17 (2): 85-96.

Takarini, N. and Hendrarini H. 2011. "Financial Ratio and Its Effect on Company Stock Prices Registered in the Jakarta Islamic Index." Journal of Business and Banking 1(2): 93-104

Watung, R. W., \& Ilat, V. 2016. "Pengaruh Return On Aset (ROA), Net Profit Margin (NPM), Dan Earning Per Share (EPS) Terhadap Harga Saham Pada Perusahaan Perbankan Di Bursa Efek Indonesia Periode 2011-2015." Jurnal EMBA : Jurnal Riset Ekonomi Manajemen Bisnis dan Akuntansi 4 (2): 518-29.

Yulsiati, H. 2016. "Pengaruh Earning Per Share, Return On Equity Dan Debt to Equity Ratio Terhadap Harga Saham Dalam Jakarta Islamic Index (JII) Yang Terdaftar Di Bursa Efek Indonesia Periode 20102014, 2(1), 104-127." Jurnal Adminika 2 (1): 104-27.

http://www.idx.co.id

http://www.bi.go.id

http://yahoo.com 